\title{
DO THE USE HEMODIALYSIS MORE FREQUENCY ON POOR?: EVIDENCE FROM Dr. SOEHADI PRIJONEGORO HOSPITAL SRAGEN, CENTRAL JAVA
}

\author{
Anisa Andriani1), Didik Gunawan Tamtomo²), Bhisma Murti3) \\ 1)Masters Program in Public Health, Universitas Sebelas Maret \\ 2)Faculty of Medicine, Universitas Sebelas Maret
}

\begin{abstract}
Background: Patients with chronic renal failure should adhere to dialysis therapy management, which consists of hemodialysis attendance, prescribed medications, fluid restrictions, and proper dietary intake. Non-adherence to the therapies may increase the morbidity and mortality rate, which indirectly affects quality of life. This study aimed to assessed factors associated with hemodialysis uptake in chronic renal failure patients.

Subjects and Method: This was an analytic observational study with cross sectional design. The study was conducted at Dr. Soehadi Prijonegoro hospital, Sragen, Central Java, in January 2020. A sample of 120 patients with chronic renal failure who did hemodialysis was selected for this study. The dependent variable was adherence toward hemodialysis. The independent variables were knowledge, length of treatment, and family income. The data were collected by questionnaire and analyzed by a multiple logistic run on Stata 13 . Results: Hemodialysis uptake in chronic renal failure patients was positively increased with high knowledge toward hemodialysis $(\mathrm{OR}=4.81 ; 95 \% \mathrm{CI}=1.65$ to $2.62 ; \mathrm{p}=0.004)$, length of treatment ( $\mathrm{OR}=8.15 ; 95 \% \mathrm{CI}=3.12$ to $4.29 ; \mathrm{p}<0.001)$, and high family income $(\mathrm{OR}=1.50 ; 95 \% \mathrm{CI}=0.54$ to $0.80 ; \mathrm{p}=0.426)$.

Conclusion: Hemodialysis uptake in chronic renal failure patients is positively increased with high knowledge toward hemodialysis, length of treatment, and high family income.
\end{abstract}

Keywords: hemodialysis, chronic renal failure, length of treatment

\section{Correspondence:}

Anisa Andriani. Masters Program in Public Health, Universitas Sebelas Maret. Jl. Ir. Sutami 36A, Surakarta 57126, Central Java. Email: andrianianisa390@gmail.com. Mobile: +6282220826660 . 